\title{
Patterns of spatial distribution and behaviour of fish on a rocky intertidal platform at high tide
}

\author{
Cláudia Faria*, Vítor C. Almada \\ Unidade de Investigação em Eco-Etologia, Instituto Superior de Psicologia Aplicada, Rua Jardim do Tabaco 34, \\ 1149-041 Lisboa, Portugal
}

\begin{abstract}
We describe the patterns of spatial distribution and behaviour of an intertidal fish assemblage on a rocky intertidal platform in the south of Portugal during high tide. Data were collected by surveying a number of predefined transects and focal observations of individual fish. Several interspecific differences, in both zonation and substratum, were found at high tide that were not apparent in observations of pools at low tide. Parablennius sanguinolentus occurred mainly on boulders at the high intertidal, Lipophrys pholis and Coryphoblennius galerita were especially abundant in the upper intertidal. L. Canevae and L. trigloides were most abundant in the low intertidal, with $L$. canevae being restricted to that level. Gobius cobitis used all shore levels, including a significant presence in the subtidal. Species typically considered subtidal, like P. pilicornis and P. gattorugine, were found also in the intertidal at high tide. In the case of $P$. gattorugine both juveniles and even large adults moved up with the tide, reaching the highest shore levels. C. galerita seemed to be restricted to the vicinity of its low-tide shelters, around crevices and pools, while large specimens of L. pholis and G. cobitis were subject to larger displacements, up and down with the tide. Apart from the benthic component, the fish assemblage is enriched at high tide by a large number of fish, mainly juveniles of pelagic and bentho-pelagic species, meaning that the rocky intertidal may play a nursery role for several non-resident fish species.
\end{abstract}

KEY WORDS: Tidal rhythms · Vertical fish movements $\cdot$ Rocky-intertidal fish communities $\cdot$ Hightide fish behaviour $\cdot$ Blenniidae $\cdot$ Gobiidae

Resale or republication not permitted without written consent of the publisher

\section{INTRODUCTION}

Most of the information on the behaviour and ecology of rocky-intertidal fish species is based on observations made during low tide, when fish are confined to tidal pools, space beneath boulders, algae, or crevices (see Gibson 1972, 1982, 1986, Horn et al. 1999, Faria \& Almada 2001). There are, however, several lines of evidence that clearly indicate that information collected at low tide provides a biased picture of these communities. Studies of activity rhythms consistently show that the activity level of rocky-intertidal resident fish tends to oscillate with the tidal cycle, being lowest at low tide (e.g. Gibson 1967a, 1971).

Several intertidal fish guard eggs in nests in crevices and holes or under stones that become emersed when the tide is low, so that courtship, feeding and even larval hatching are necessarily limited to high tide (e.g. Almada et al. 1992). Marking experiments have shown that rocky-intertidal fishes have restricted movements and good homing abilities (e.g. Williams 1957, Gibson 1967b, Green 1971). However, the available information is mostly limited to low-tide observations of the fish at points of release and recapture, little being known of what happens during tidal submersion inbetween.

Among the few studies that address the behaviour of intertidal fish during high tide (e.g. Gibson 1972, Ralston \& Horn 1986, Burrows et al. 1999; for a review see Gibson 1999), that of Burrows et al. (1999) is worth further mention. Using underwater TV observations of a rocky shore they suggested that the shanny Lipophrys 
pholis (Linnaeus, 1758) shows a higher level of activity during the ebbing and high-tide periods, concentrating their movements around crevices.

On the other hand, during high tide, substantial numbers of non-resident fish are known to move to the rocky intertidal habitat (e.g. Gibson 1982, Yoshiyama et al. 1986, Black \& Miller 1991, Macpherson 1994), and may play very significant ecological roles in these communities. There is a large body of literature that emphasises the role of estuaries (e.g. Lenanton \& Potter 1987), salt marshes and mangroves (e.g. Laegdsgaard \& Johnson 1995), coastal lagoons (e.g. Antunes et al. 1988), sandy beaches (e.g. Gibson 1982, Nash et al. 1994), or other shallow-water areas (e.g. Layman 2000) as nurseries for many marine fishes. However, the data available for rocky shores are much less abundant (e.g. Gibson 1982, Henriques \& Almada 1998).

In the present paper, we studied the use of rocky intertidal habitats by non-resident fishes and the patterns of space utilisation of the most common intertidal resident fish species during high tide. Concerning the resident fish, 2 contrasting hypotheses were tested: resident rocky-intertidal fishes move up and down with the tide, maximising submersion time and feeding opportunities, versus those fishes that maintain an approximately constant position at a given level of the shore, minimising their distances from shelter sites and the time they remain exposed.

\section{MATERIALS AND METHODS}

The study area was a sheltered rocky platform in the Algarve (Praia da Luz, Portugal; $37^{\circ} 06^{\prime} \mathrm{N}, 8^{\circ} 40^{\prime} \mathrm{W}$ ). In choosing the study location 2 considerations were taken into account. We selected a site where the rocky intertidal platforms were sufficiently broad so that each depth level was represented by an area as large as possible to ensure maximum sampling opportunities. On the other hand, it was absolutely necessary to select a site with minimal turbulence, as this kind of work is virtually impossible even in moderately rough seas. In this area of Portugal, the south-facing coast is relatively protected, especially during spring and summer, when north winds are common. The rocky intertidal extends from a cliff with a gentle slope and presents many pools and channels. Boulders and sandy patches are found at the bottom of the channels, and algal cover is very reduced. In this part of the Atlantic, the tidal amplitude typically ranges between 1.5 and $2.3 \mathrm{~m}$ (average $=1.86 \mathrm{~m}, \mathrm{SD}=0.31, \mathrm{n}=10$ ) in neap tides and between 2 to 9 and $4.0 \mathrm{~m}$ (average $=3.52 \mathrm{~m}$, $\mathrm{SD}=0.39, \mathrm{n}=10$ ) in spring tides (data from Instituto Hidrográfico Português).
Eight $40 \mathrm{~m}$ transect lines (kept in position on the ocean bottom by lead weights), with marks placed every $2 \mathrm{~m}$, were positioned perpendicularly to the shoreline, from the cliff down to whatever depth was reached by the line. The distance between adjacent transects was $9 \mathrm{~m}$. The profile of the shore was sufficiently homogeneous throughout the study area to make the different transects comparable, i.e. a given distance from the start of a transect corresponded roughly to a similar shore level for all transects.

The area covered by these lines was divided into 2 sections: (A) the first $30 \mathrm{~m}$ of the lines, corresponding to the intertidal area of the platform, subject to water tidal movements and (B) from 30 to $40 \mathrm{~m}$ of the lines, corresponding to the subtidal area of the platform, that is, the section that was always submerged even during low tide. Section A was further sub-divided into 3 sub-sections: the first $10 \mathrm{~m}$ (A1), which was submerged only by high spring tides; 10 to $20 \mathrm{~m}$ (A2), which was submerged in both spring and neap tides, but was the first to be emersed during the ebbing tide and the last to be submerged by the flooding tide (typically it was submerged only $<3 \mathrm{~h}$ before high tide occurred); and 20 to $30 \mathrm{~m}$ (A3), which was totally submerged $2 \mathrm{~h}$ after low tide. The area studied encompassed $2520 \mathrm{~m}^{2}$.

The observations were based on visual censuses along transects parallel to the coast, from Line 1 to 8,3 transects in Area B, 3 in Area A3 and when possible 3 in Areas A2 and A1 (only during the high-tide phase), with intervals of $2 \mathrm{~m}$ between successive transects. Due to turbulence and habitat complexity, the visual inspection of each transect was limited to about $50 \mathrm{~cm}$ for each side of the transect line, so that observations of contiguous transects did not occur.

On each day, 2 snorkelling dives were always performed (with a mean duration of $1 \mathrm{~h} 30 \mathrm{~min}$ to $2 \mathrm{~h}$ each), with intervals of 1 to $2 \mathrm{~h}$ between them, to cover 2 of the 3 distinct phases of the same tidal cycle: the rising tide, which corresponds to the submersion period that permits the diver to swim over the platform (30 to $40 \mathrm{~cm}$ of water) up to $1 \mathrm{~h}$ before high tide (60 to $100 \mathrm{~cm}$ of water); the high-tide phase, which includes the period $1 \mathrm{~h}$ before to $1 \mathrm{~h}$ after high tide; and the ebbing phase, which was from $1 \mathrm{~h}$ after high tide $(60$ to $100 \mathrm{~cm}$ of water) to the emersion period that permits the diver to swim over the platform (30 to $40 \mathrm{~cm}$ of water).

For each dive, the benthic and the pelagic and bentho-pelagic species were sampled in different censuses. For each fish observed, the species and size class $(<3 \mathrm{~cm}, 3$ to $10 \mathrm{~cm}, 10$ to $15 \mathrm{~cm}$ and $>15 \mathrm{~cm}$ in the case of pelagic and bentho-pelagic species; $<3 \mathrm{~cm}, 3$ to $5 \mathrm{~cm}, 5$ to $7 \mathrm{~cm}$ and $>7 \mathrm{~cm}$ in the case of benthic species) were recorded on an underwater writing pad. Size was visually estimated taking as a reference a 
ruler drawn in the writing pad. In the case of benthic fish, the substratum where it was observed and its behaviour were also recorded. Fish identification was based on Corbera et al. (1996) and the nomenclature follows Whitehead et al. (1986).

From April 2003 to June 2005 a total of 34 dives were performed (totalling $72 \mathrm{~h}$ ): 9 during the rising tide and 9 during the high tide of the same day and 8 during the high tide and 8 during the ebbing tide of the same day. Sea conditions did not allow the number of dives to be equal in all months. Indeed, such dives, in very close proximity to the rocks and in areas of breaking waves, were only possible when turbulence was minimal and were never attempted if the sea was rough. Poor conditions were especially frequent during the winter and, in practice, made diving in January and February unfeasible. This limitation imposed by the sea conditions means that variations in turbulence that could affect both fish behaviour and the divers' ability to record it were minimal for all dives.

In addition to the dives described above, focal observations of 10 min each, in which an individual fish was continually observed (sensu Martin \& Bateson 1993) or until the fish moved out of sight of the observer, were also made on the most common intertidal benthic fish present on the rocky platform. A total of 36 fish were followed; for each fish, we recorded the behaviours exhibited and the distances travelled. As the time of day could also affect feeding activities (e.g. Taborsky \& Limberger 1980), we made this as fixed as possible by selecting afternoon tides in the period from 12:00 to 19:00 h.

Statistical analysis was performed using the computer program Statistica 5.0 for Windows (Statsoft). The contingency tables analysis was performed using the simulation statistical procedure ACTUS (Estabrook \& Estabrook 1989). In an attempt to quantify the patterns of vertical distribution of each resident species, each record of every resident fish was assigned a score (depth score), on a scale of 4 points, as follows: 1 for fish recorded in the Area B (subtidal), 2 for fish recorded in the Area A3, 3 for fish recorded in the Area A2 and 4 for fish recorded in the Area A1. For each species, the mean depth score indicates the level where most occurrences were concentrated, whereas the dispersion around the mean provides an estimate of the diversity of depth ranges at which the species were found. To allow direct comparisons across species, the dispersion was expressed as the coefficient of variation (average, $\pm \mathrm{SD}$ ). As a way to ordinate the data and visualise the patterns obtained, a correspondence analysis was performed using the mean depth scores and the coefficient of variation for each species.

\section{RESULTS}

\section{Pelagic and bentho-pelagic species}

A total of 11499 fish records were made in the study period, corresponding to 19 pelagic or bentho-pelagic species, 9 of them with commercial value (the European seabass Dicentrarchus labrax [Linnaeus, 1758]; white sea bream Diplodus sargus [Linnaeus, 1758]; common 2-banded sea bream Diplodus vulgaris [E. G. Siant-Hilaire, 1818]; striped red mullet Mullus surmuletus Linnaeus, 1758; salema Sarpa salpa [Linnaeus, 1758]; gilt-head sea bream Sparus aurata Linnaeus, 1758; Atlantic mackerel Scomber scombrus Linnaeus, 1758; and the Mugilidae and the unidentified Soleidae) (Table 1), together with 3 records of cuttlefish Sepia officinalis (Linnaeus, 1758) and 4 records of the common octopus Octopus vulgaris Cuvier, 1797.

During the study period the highest number of individuals occurred in October, November and December, i.e. in the coldest months in which dives were made (Fig. 1). Although typically on the Portuguese shore sea surface temperature peaks in September and begins to decline during autumn (data from Instituto Português de Meteorologia), the water temperature over the intertidal platform during this study reached its peak in June and July $\left(18\right.$ to $20^{\circ} \mathrm{C}$ in June and July; 16 to $17^{\circ} \mathrm{C}$ in November and December). This may have been caused by a similar trend in air temperature. This increase in fish abundance between October and December held for the majority of the species

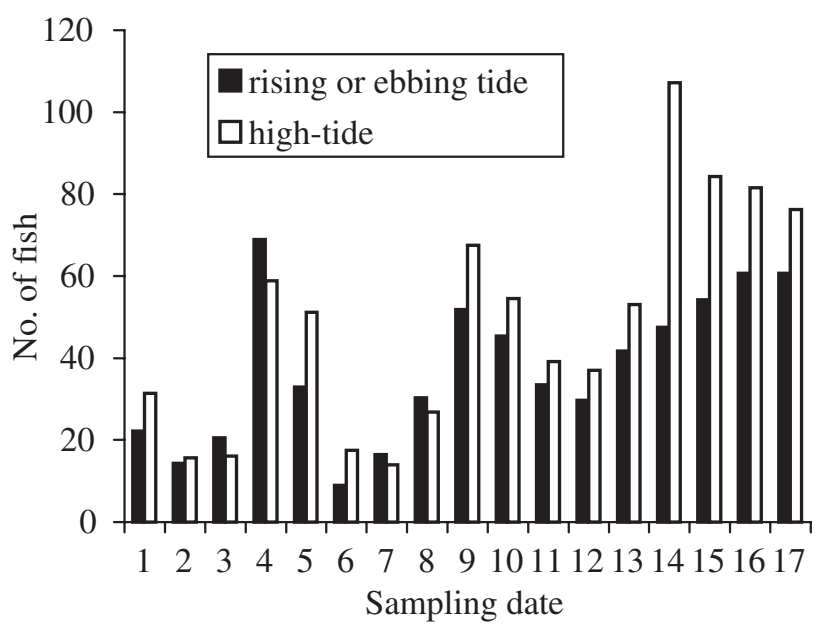

Fig. 1. Number of fish per transect observed in each tidal phase, for all pelagic and bentho-pelagic species, at each date sampled: (1) 9 April 2004, (2) 6 May 2004, (3) 24 May 2004, (4) 14 May 2005, (5) 29 May 2005, (6) 3 June 2004, (7) 8 June 2004, (8) 22 June 2004, (9) 16 June 2005, (10) 6 July 2004, (11) 12 July 2004, (12) 27 July 2004, (13) 6 September 2004, (14) 12 October 2004, (15) 17 October 2004, (16) 13 November 2004 and (17) 8 December 2004 
Table 1. Total number of fish of each pelagic and bentho-pelagic species observed on each section (B: subtidal area; A: intertidal area, subdivided into sub-sections 1, 2 and 3) per tidal phase (Symphodus spp. includes the corkwing Symphodus melops and the 5spotted wrasse Symphodus roissali). There were 17 dives during the rising or ebbing phase and 17 dives during the high-tide phase

\begin{tabular}{|c|c|c|c|c|c|c|c|}
\hline Family & Species & $\begin{array}{c}\text { Rising or } \\
\text { ebbing tide }\end{array}$ & High tide & $\begin{array}{l}\text { Rising or } \\
\text { ebbing tide }\end{array}$ & High tide & $\begin{array}{c}\text { A2 } \\
\text { High tide }\end{array}$ & $\begin{array}{c}\text { A1 } \\
\text { High tide }\end{array}$ \\
\hline Atherinidae & Atherina sp. & 329 & 294 & 122 & 410 & 256 & 10 \\
\hline \multirow[t]{4}{*}{ Labridae } & Coris julis & 47 & 80 & 34 & 62 & 2 & 0 \\
\hline & Labrus bergylta & 7 & 19 & 4 & 17 & 11 & 0 \\
\hline & Symphodus bailoni & 8 & 14 & 1 & 7 & 0 & 0 \\
\hline & Symphodus spp. & 426 & 671 & 337 & 1006 & 566 & 33 \\
\hline Mugilidae & Unidentified & 40 & 86 & 25 & 53 & 43 & 0 \\
\hline Mullidae & Mullus surmuletus & 3 & 0 & 0 & 0 & 0 & 0 \\
\hline Moronidae & Dicentrarchus labrax & 4 & 16 & 34 & 11 & 7 & 0 \\
\hline Scombridae & Scomber scombrus & 0 & 19 & 0 & 0 & 0 & 0 \\
\hline Soleidae & Unidentified & 8 & 0 & 0 & 1 & 0 & 0 \\
\hline \multirow[t]{8}{*}{ Sparidae } & Boops boops & 50 & 3 & 10 & 50 & 20 & 10 \\
\hline & Diplodus cervinus & 37 & 16 & 51 & 46 & 44 & 8 \\
\hline & Diplodus puntazzo & 0 & 0 & 1 & 1 & 8 & 0 \\
\hline & Diplodus sargus & 585 & 532 & 874 & 805 & 888 & 102 \\
\hline & Diplodus vulgaris & 483 & 658 & 230 & 418 & 166 & 8 \\
\hline & Sarpa salpa & 30 & 80 & 22 & 30 & 29 & 0 \\
\hline & Sparus aurata & 30 & 1 & 0 & 31 & 0 & 0 \\
\hline & Spondyliosoma cantharus & 4 & 1 & 6 & 33 & 1 & 0 \\
\hline Trachinidae & Echiichthys vipera & 1 & 3 & 0 & 0 & 0 & 0 \\
\hline
\end{tabular}

(Kendall's coefficient of concordance $W=0.72, \mathrm{p}=$ $0.0001, \mathrm{n}=17, \mathrm{df}=12 ; 8$ species were excluded because they were present on $<7$ sampling days).

The dominant species with respect to numbers of individuals were Diplodus sargus (33\%), Symphodus spp. $(27 \%)$ and Diplodus vulgaris $(17 \%)$. For the majority of species only juveniles were found, except for Atherina sp., rainbow wrasse Coris julis (Linneus, 1758) and Symphodus spp., for which some adults were also observed (fish $>15 \mathrm{~cm}$ ). For 3 species $(C$. julis, D. sargus and the unidentified Soleidae) fish $<3 \mathrm{~cm}$, which most likely had recruited recently, were observed in moderate numbers $(3$ recruits for $C$. julis and 2 recruits for the unidentified Soleidae in September and October; 133 recruits for $D$. sargus between April and July).

Although there were no differences in the number of species or the number of fish in the subtidal zone between the 3 tidal phases considered (rising tide versus high tide and high tide versus ebbing tide) (Wilcoxon matched pairs tests - number of species: rising tide versus high tide, $Z=0.11, \mathrm{p}=0.917, \mathrm{n}=9$; high tide versus ebbing tide, $Z=0.94, \mathrm{p}=0.345, \mathrm{n}=8$; number of fish: rising tide versus high tide, $Z=0.53, \mathrm{p}=$ $0.594, \mathrm{n}=9$; high tide versus ebbing tide, $Z=0.98, \mathrm{p}=$ $0.327, \mathrm{n}=8$ ), there was an increase in the number of species or fish in the intertidal zone (A3) during the high-tide period (Wilcoxon matched pairs testsnumber of species: rising tide versus high tide, $Z=$
2.20, $\mathrm{p}=0.028, \mathrm{n}=9$; high tide versus ebbing tide, $Z=$ 2.03, $\mathrm{p}=0.042, \mathrm{n}=8$; number of fish: rising tide versus high tide, $Z=2.04, \mathrm{p}=0.042, \mathrm{n}=9$; high tide versus ebbing tide, $Z=2.52, \mathrm{p}=0.012, \mathrm{n}=8$ ).

Almost all species seemed to occupy almost the entire study area during the high-tide period. However, 4 species (the lesser weever Echiichthys vipera [Cuvier, 1829], Mullus surmuletus, Scomber scombrus and the unidentified Soleidae) occurred only in the subtidal or A3 in sand (Table 1). Coris julis, Dicentrarchus labrax, Diplodus vulgaris, Sarpa salpa, the black sea bream Spondyliosoma cantharus (Linnaeus, 1758) and an unidentified Mugilidae were observed more frequently in the subtidal than in the intertidal zone, whereas Symphodus spp. were observed more frequently in A3 and A2. On the other hand, only 6 species (Atherina sp.; the bogue Boops boops [Linnaeus, 1758]; the zebra sea bream Diplodus cervinus [Lowe, 1841]; Diplodus sargus, D. vulgaris and Symphodus spp.) moved to the high intertidal (A1) during the hightide period, 3 of them in significantly high numbers $(B$. boops, D. cervinus and D. sargus) $\left(\chi^{2}=1017.52, \mathrm{df}=54\right.$, $\mathrm{p}=0.0001)$.

\section{Benthic species}

A total of 2347 fish records were made in the study period, corresponding to 10 benthic species. The high- 


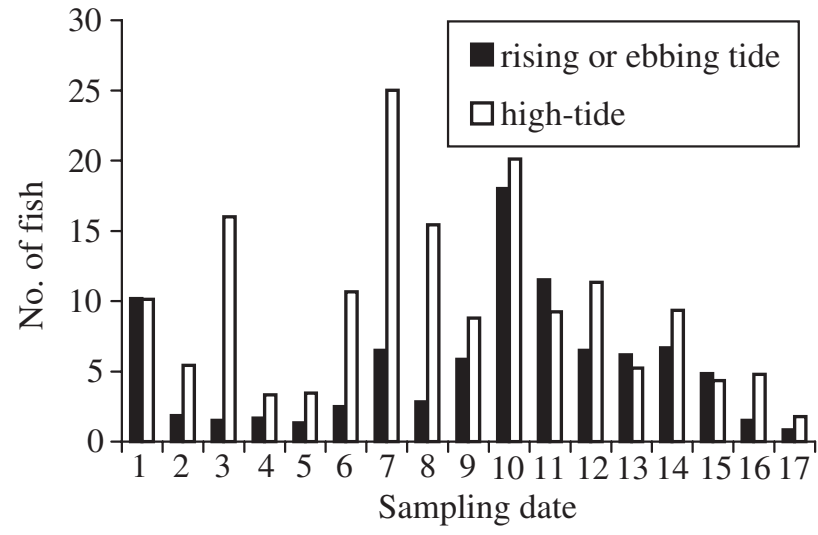

Fig. 2. Number of fish per transect observed in each tidal phase, for all benthic species, at each date sampled (dates as in Fig. 1)

est number of individuals occurred in June and July, contrary to the pelagic and bentho-pelagic species (Fig. 2). This trend was consistent across species (Kendall's coefficient of concordance $W=0.75, \mathrm{p}=$ $0.0001, \mathrm{n}=17, \mathrm{df}=6 ; 3$ species were excluded because they were present on $<7$ sampling days). The dominant species, with respect to numbers of individuals, were Lipophrys pholis (53\%), the Montagu's blenny Coryphoblennius galerita (Linnaeus, 1758) (20\%), the giant goby Gobius cobitis Pallas, 1811 (14\%), followed by the ringneck blenny Parablennius pilicornis (Cuvier, 1829) (5\%) and Lipophrys trigloides (Valenciennes, 1836) (5\%) in smaller numbers.

The distribution of depth scores for the benthic species is presented in Table 2, together with the respective coefficient of variation. Inspection of this table reveals a number of specific patterns of vertical distribution that are not apparent when only low-tide observations are made:

(1) Callionymus sp. and Pomatoschistus sp. were strictly subtidal, presenting the lowest mean depth records and a coefficient of variance of 0 .

(2) Parablennius pilicornis, usually considered a subtidal resident, showed a low mean depth score but a higher coefficient of variation reflecting its sporadic visits to the intertidal ( $16 \%$ of records). It is worth mentioning that $P$. pilicornis, in spite of being in the subtidal zone, seems to be more active in the high-tide period (34 fish recorded during the rising or ebbing tide; 84 fish recorded during high tide).

(3) Lipophrys canevae (Vinciguerra, 1880) and the tompot blenny Parablennius sanguinolentus (Pallas, 1811) were also restricted to a very limited depth range, as expressed by their coefficients of variation, with the difference that $L$. canevae is a specialist of the low intertidal (A3), whereas the rusty blenny $P$. sanguinolentus is a specialist of the highest intertidal (A2).
(4) Coryphoblennius galerita, Lipophrys pholis and Gobius cobitis have mean depth scores that were not very different from that of Parablennius sanguinolentus, but their coefficients of variation were very different. This means that they were recorded in a much wider band on the shore. Some records of these species, frequently considered typical intertidal residents, were made in the subtidal ( $2 \%$ for C. galerita and L. pholis and $11 \%$ for G. cobitis). For the first 2 species, the majority $(>60 \%)$ of the individuals recorded in the subtidal was observed in the first $2 \mathrm{~m}$ at the uppershore limit of that area, but for G. cobitis, which showed the second highest coefficient of variation, the subtidal observations were evenly distributed over all $10 \mathrm{~m}$ of the area studied, meaning that the fish occurring in the last few metres at the lower-shore limit of the study area could be found at depths of $>3 \mathrm{~m}$.

(5) Lipophrys trigloides has a coefficient of variation similar to that of Coryphoblennius galerita and Lipophrys pholis, but a lower mean, suggesting that, although frequent in several levels of the intertidal, it tends to occur further down-shore than the other 2 species. For this species, $16 \%$ of the records was in the subtidal.

(6) A striking result concerns Parablennius gattorugine (Brünnic, 1768). Traditionally viewed as a subtidal species, with only some juveniles visiting the intertidal, it presented the highest coefficient of variation and a mean score of 2.08 . These values indicate that most records were intertidal (64\% of records) and widely dispersed among levels (from A3 to A1). The presence of this species in the intertidal was not limited to juveniles, but was due to a tidal migration of large numbers of individuals, both juveniles and adults.

The results of the correspondence analysis applied to the benthic species are presented in Fig. 3. Two factors explained $93 \%$ of the total variance (92 and $0.06 \%$ being explained by the first and the second factor,

Table 2. Mean depth scores and coefficient of variation (CV) for each benthic species

\begin{tabular}{|lcccc|}
\hline Family/Species & Mean & SD & Range & CV \\
\hline Blenniidae & & & & \\
$\quad$ Coryphoblennius galerita & 2.61 & 0.62 & $1-4$ & 0.24 \\
$\quad$ Lipophrys canevae & 2.00 & - & $2-2$ & 0.00 \\
$\quad$ Lipophrys pholis & 2.69 & 0.60 & $1-4$ & 0.22 \\
$\quad$ Lipophrys trigloides & 2.11 & 0.62 & $1-3$ & 0.29 \\
$\quad$ Parablennius gattorugine & 2.08 & 0.88 & $1-4$ & 0.42 \\
$\quad$ Parablennius pilicornis & 1.17 & 0.38 & $1-2$ & 0.32 \\
$\quad$ Parablennius sanguinolentus & 2.80 & 0.60 & $2-4$ & 0.21 \\
Gobiidae & & & & \\
$\quad$ Gobius cobitis & 2.52 & 0.84 & $1-4$ & 0.33 \\
$\quad$ Pomatoschistus sp. & 1.00 & - & $1-1$ & 0.00 \\
Callionymidae & & & & \\
$\quad$ Callionymus sp. & 1.00 & - & $1-1$ & 0.00 \\
\hline
\end{tabular}




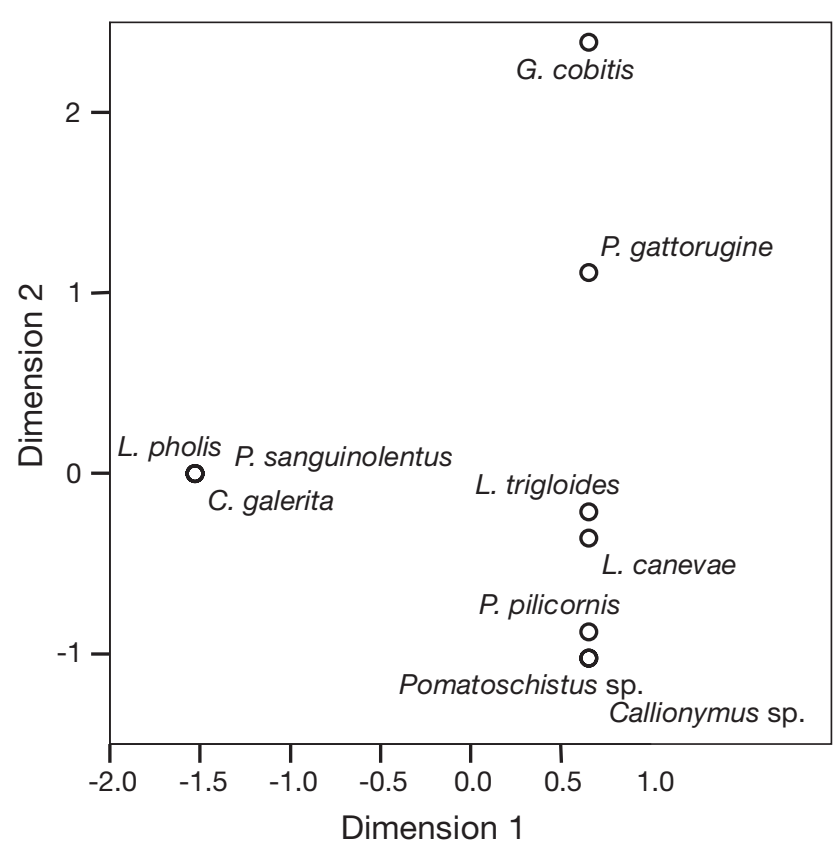

Fig. 3. Results of the correspondence analysis, in which for each benthic species the mean depth score and the coefficient of variation were included as variables (for full taxonomic designations see Table 2)

respectively). As shown in Fig. 3, 4 groups were separated by this analysis. One comprised subtidal species (Callionymus sp., Parablennius pilicornis and Pomatoschistus sp.); the second comprised Lipophrys canevae and Lipophrys trigloides-although occurring in the intertidal they were most abundant in the lower part of the intertidal; the third group included the species that most intensively used the upper intertidal (Coryphoblennius galerita, Lipophrys pholis and Parablennius sanguinolentus); and the fourth group, especially differentiated by the second axis, comprised Gobius cobitis and Parablennius gatorugine, which differ from the remaining species by their very wide spectrum of occurrence, ranging from the subtidal to the upper intertidal.

Concerning the type of bottom where each species was observed more frequently (Table 3), Coryphoblennius galerita, Lipophrys canevae, Lipophrys pholis, Lipophrys trigloides and Parablennius gattorugine were predominantly observed on rock; Gobius cobitis was observed on rock, sand and boulders, Parablennius pilicornis on algae, Parablennius sanguinolentus on boulders, and Pomatoschistus sp. and Callionymus sp. on sand. However, L. trigloides and $P$. gattorugine also occur in significantly high numbers on algae $\left(\chi^{2}=1866.07, \mathrm{df}=27, \mathrm{p}=0.0001\right)$. These substratum preferences are similar to those described for low tide (e.g. Macpherson 1994, Faria et al. 1998, Mesa \&
Vacchi 2005), with the important difference that when the tide was high large G. cobitis were found on exposed rocky substratum.

Considering the number of larger individuals $(>7 \mathrm{~cm}$ for Lipophrys pholis and $>5 \mathrm{~cm}$ for Coryphoblennius galerita) observed in the A3 zone of the intertidal during the 3 different phases of the tidal cycle (Table 4), there was some decrease in the number of L. pholis in this zone during the high-tide phase compared to the rising or ebbing phases (Wilcoxon matched pairs tests - rising tide versus high tide, $Z=2.20, \mathrm{p}=0.028$, $\mathrm{n}=9$; high tide versus ebbing tide, $Z=2.52, \mathrm{p}=0.012$, $\mathrm{n}=8$ ). However, for $C$. galerita there were no significant differences between the 3 tidal phases (Wilcoxon matched pairs tests - rising tide versus high tide, $Z=$ $1.12, \mathrm{p}=0.263, \mathrm{n}=9$; high tide versus ebbing tide, $Z=$ $0.41, \mathrm{p}=0.686, \mathrm{n}=8$ ).

There was also some decrease in the numbers of Gobius cobitis during the high-tide phase compared to the rising tide (Wilcoxon matched pairs tests - rising tide versus high tide, $Z=2.37, \mathrm{p}=0.018, \mathrm{n}=9$ ), but there were no significant differences between the ebbing phase and the high tide (Wilcoxon matched pairs tests - high tide versus ebbing tide, $Z=0.27, \mathrm{p}=$ $0.787, \mathrm{n}=8$ ). It is possible that for this species the sampling obtained was not large enough to detect a clear pattern. Additionally, it could be influenced by some seasonal effects that were not clarified with the available data.

Although usually Area A2 surveys were only possible at high tide, on 4 occasions they were also possible in other tidal phases: on 2 occasions during the rising tide and on 2 occasions during the ebbing tide. When the high-tide numbers of these 4 surveys were compared with the corresponding surveys for intermediate phases of the tidal cycle, a trend similar to that described for Area A3 was observed. The numbers of Lipophrys pholis and Gobius cobitis were lower at high tide, whereas for Coryphoblennius galerita no appreciable differences were noted (Table 4).

Table 3. Number of fish of each benthic species observed on each type of bottom

\begin{tabular}{|lrrrr|}
\hline Species & Algae & Boulders & Rock & Sand \\
\hline Coryphoblennius galerita & 17 & 0 & 418 & 0 \\
Lipophrys canevae & 0 & 0 & 9 & 0 \\
Lipophrys pholis & 0 & 6 & 1225 & 6 \\
Lipophrys trigloides & 34 & 0 & 78 & 0 \\
Parablennius gattorugine & 9 & 0 & 15 & 0 \\
Parablennius pilicornis & 112 & 0 & 0 & 7 \\
Parablennius sanguinolentus & 0 & 38 & 5 & 0 \\
Gobius cobitis & 6 & 51 & 138 & 96 \\
Pomatoschistus sp. & 0 & 0 & 0 & 7 \\
Callionymus sp. & 0 & 0 & 0 & 3 \\
\hline
\end{tabular}


Table 4. Lipophrys pholis ( $>7 \mathrm{~cm})$, Coryphoblennius galerita $(>5 \mathrm{~cm})$ and Gobius cobitis $(>7 \mathrm{~cm})$. Number of fish observed in Sub-sections A3 and A2 during the 3 tidal phases: (1) rising tide; (2) high tide and (3) ebbing tide

\begin{tabular}{|c|c|c|c|c|c|c|c|c|c|c|c|c|c|c|c|c|c|c|}
\hline \multirow{3}{*}{ Date } & \multicolumn{9}{|c|}{ Section A3 } & & & & \multicolumn{6}{|c|}{ - Section A2 } \\
\hline & \multicolumn{3}{|c|}{ L. pholis } & \multicolumn{3}{|c|}{ C. galerita } & \multicolumn{3}{|c|}{ G. cobitis } & \multicolumn{3}{|c|}{ L. pholis } & \multicolumn{3}{|c|}{ C. galerita } & \multicolumn{3}{|c|}{ G. cobitis } \\
\hline & 1 & 2 & 3 & 1 & 2 & 3 & 1 & 2 & 3 & 1 & 2 & 3 & 1 & 2 & 3 & 1 & 2 & 3 \\
\hline 09/04/04 & 24 & 75 & & 14 & 2 & & 2 & 0 & & & & & & & & & & \\
\hline 06/05/04 & 8 & 0 & & 2 & 0 & & 0 & 0 & & & & & & & & & & \\
\hline $24 / 05 / 04$ & 0 & 0 & & 6 & 3 & & 0 & 0 & & & & & & & & & & \\
\hline 03/06/04 & 2 & 0 & & 1 & 0 & & 6 & 0 & & & & & & & & & & \\
\hline 08/06/04 & 16 & 2 & & 10 & 13 & & 2 & 0 & & & & & & & & & & \\
\hline $22 / 06 / 04$ & 0 & 0 & & 1 & 2 & & 6 & 0 & & 47 & 3 & & 5 & 1 & & 7 & 4 & \\
\hline 06/07/04 & 104 & 0 & & 7 & 9 & & 16 & 5 & & & & & & & & & & \\
\hline $12 / 07 / 04$ & & 0 & 33 & & 0 & 2 & & 3 & 9 & & & & & & & & & \\
\hline $27 / 07 / 04$ & & 3 & 12 & & 3 & 3 & & 18 & 0 & & & & & & & & & \\
\hline 06/09/04 & 18 & 3 & & 0 & 9 & & 3 & 0 & & & & & & & & & & \\
\hline $12 / 10 / 04$ & & 0 & 27 & & 0 & 0 & & 9 & 3 & & & & & & & & & \\
\hline $17 / 10 / 04$ & & 0 & 3 & & 2 & 20 & & 2 & 2 & & 2 & 4 & & 6 & 2 & & 0 & 1 \\
\hline $13 / 11 / 04$ & & 0 & 5 & & 1 & 0 & & 5 & 3 & & 0 & 2 & & 1 & 1 & & 2 & 2 \\
\hline $08 / 12 / 04$ & & 0 & 2 & & 2 & 1 & & 0 & 0 & & & & & & & & & \\
\hline $14 / 05 / 05$ & 0 & 0 & & 6 & 8 & & 2 & 0 & & 3 & 0 & & 3 & 3 & & 0 & 0 & \\
\hline $29 / 05 / 05$ & & 1 & 3 & & 2 & 3 & & 0 & 0 & & & & & & & & & \\
\hline $16 / 06 / 05$ & & 0 & 5 & & 8 & 9 & & 10 & 1 & & & & & & & & & \\
\hline
\end{tabular}

These different patterns of change of distribution with the tidal cycle were also supported by focal observations. Gobius cobitis and Lipophrys pholis exhibited larger displacements than Coryphoblennius galerita (G. cobitis: average $=117.5 \mathrm{~cm}, \mathrm{SD}=236.72$, range $=10$ to $600 \mathrm{~cm}, \mathrm{n}=6 ;$ L. pholis: average $=104.76 \mathrm{~cm}, \mathrm{SD}=$ 115.7, range $=10$ to $500 \mathrm{~cm}, \mathrm{n}=21$; C. galerita: average $=61.1 \mathrm{~cm}, \mathrm{SD}=53.7$, range $=10$ to $150 \mathrm{~cm}, \mathrm{n}=9$ ) as the tide rose.

Almost all species were observed feeding (except Lipophrys canevae and Pomatoschistus sp.). Coryphoblennius galerita and Lipophrys pholis preyed heavily on barnacles (but $L$. pholis showed a wider spectrum of food items than C. galerita). The other species fed mainly on organisms that were in the algae. Gobius cobitis, which is considered mainly a herbivorous fish, was observed eating other fish (a fact already noted by Gibson 1970). In general, a higher number of fish fed during the rising tide $(45 \%)$ or high tide $(38 \%)$ than during the ebbing tide $(16 \%)\left(C\right.$. galerita: $\chi^{2}=$ 127.43, df $=2, \mathrm{p}=0.0001 ;$ L. pholis: $\chi^{2}=38.18, \mathrm{df}=2$, $\mathrm{p}=0.0001$; for other species the number of feeding activities observed was too small to analyse).

\section{DISCUSSION}

The rocky-littoral fish assemblage described for south Portugal is similar to those described for other rocky shore localities in the north eastern Atlantic (e.g. Gibson 1972, Beja 1995, Henriques \& Almada 1998). Diplodus spp., Symphodus spp., Coryphoblennius galerita, Gobius cobitis and Lipophrys pholis are consistent components of the littoral fish fauna. During the study period, this fish assemblage suffered marked fluctuations, with most pelagic and bentho-pelagic species showing peaks in occurrence in October, November and December and most benthic species in June and July. These observations suggest that such changes have a seasonal basis, but they must be interpreted with caution because, due to rough sea conditions, it was not possible to collect data during January and February.

The pattern obtained for the pelagic and benthopelagic species, also observed by Beja (1995) for the southwest coast of Portugal, seems to indicate that in Portugal these fish do not suffer a pronounced winter thermal stress, contrary to other areas in which fish reduce activity by retreating to refuges during the colder months (e.g. Darwall et al. 1993, Sayer et al. 1994).

The decreased abundance of benthic species during winter has also been observed during low tide at other rocky intertidal platforms of Portugal (Faria \& Almada 1999) and northwest Europe (e.g. Gibson 1967b, Milton 1983). Gibson (1967b), in a study conducted on intertidal fish on the west coast of France, suggested that fish, namely Lipophrys pholis, could move down shore into deeper waters during the winter months. However, the present study was conducted both in intertidal and subtidal areas, and this decrease in the numbers of fish during the winter months was observed in all habitats. Thus, it seems likely that this decrease could be related to a general reduction in 
their activity levels with low temperatures, with fish being more restricted to shelters like pools or crevices in the rock platform, and hence less easy to detect by the observer. This interpretation is supported by Qasim (1957), who also observed a decrease in the feeding condition of these fish at low temperatures.

The fish assemblage composition present at this rocky intertidal habitat was very different across the tidal cycle. According to Gibson (1982) and Gibson \& Yoshiyama (1999), intertidal fishes can be categorised as either residents or visitors, depending on whether they spend most of their life in the intertidal zone or only visit it on a regular basis. In fact, during low tide the number of species that could be found on this intertidal platform was much smaller (no more than 10 species, C. Faria pers. obs.) than during the high-tide period. During the latter period numerous tidal visitors (at least 16 pelagic or bentho-pelagic species and 2 benthic), some of them with some commercial importance, entered the intertidal zone and moved considerable distances that depended on the extent of the intertidal area available and the characteristics of each species. The majority of them used this habitat as juveniles, suggesting that it can play an important nursery role.

The few similar studies of intertidal use during high tide provide some evidence of this movement with incoming water (e.g. Gibson 1972, Black \& Miller 1991, Burrows et al. 1994), for feeding and shelter from larger fish (e.g. Rangley \& Kramer 1995), to defend intraspecific territories (e.g. Carlisle 1961), or for spawning (e.g. Potts 1985).

In the present study, it became evident that the extent of this movement into the intertidal on rising tides varies greatly with the species. Only a few species move to the high intertidal in significant numbers, probably because of the risks of physical damage, of being stranded or transported by strong water movements into unsuitable places. It is possible that these problems contribute to the relative scarcity of very small fish $(<3 \mathrm{~cm})$, which although being more numerous than older juveniles were clearly underrepresented in our observations. The use of the rock intertidal habitat by juveniles of many species, some of them with commercial value, stresses the need for the conservation of this habitat (e.g. Macpherson 1998, Macpherson \& Raventos 2005).

Resident intertidal species, i.e. fishes that after settlement live and breed in the intertidal zone (sensu Gibson 1982), by definition remain within the intertidal zone and tend to be restricted in their movements (Gibson \& Yoshiyama 1999). These species, being generally small and benthic, have limited powers of locomotion compared with the other components of this assemblage. We can consider that there are some species that are truly residents in the intertidal, like
Lipophrys canevae and Parablennius sanguinolentus and, to a slightly lesser extent, Coryphoblennius galerita and Lipophrys pholis. For the first 2 species, the only information we had until now referred to the Mediterranean (Zander 1972), where tides are often negligible. Thus, although it was known that they occupied the upper water level, their behaviour in truly tidal conditions was unknown. The 2 species differ markedly in their high tide distribution: while $L$. canevae is restricted to the low intertidal, P. sanguinolentus is especially abundant in boulder habitats that occur high on the shore.

This study also highlights for the first time the existence of ecological differences between 2 closely related species, Lipophrys pholis and Lipophrys trigloides. While L. pholis uses the full extent of the intertidal zone, with high incidence in its upper parts, $L$. trigloides shows a more restricted occurrence, being especially abundant in the low intertidal and showing a higher proportion of occurrences (up to $16 \%$ ) in the subtidal.

Gobius cobitis, often viewed as an intertidal fish, differs from the species mentioned above because of its wide spectrum of vertical distribution at high tide. Not only was it found at all levels of the intertidal, but it also occurred in appreciable numbers in the subtidal.

On the other hand, fish that were traditionally considered subtidal residents, like Parablennius gattorugine, at least as adults, and Parablennius pilicornis, were also observed with some frequency in the intertidal zone at high tide. This was particularly remarkable in the case of $P$. gattorugine, for which $>50 \%$ of the occurrences were in the intertidal area, with even large adult fishes visiting the upper part of the shore at high tide. Milton (1983), based on feeding information, has already mentioned that the adults of this species must migrate to some extent to the intertidal to feed, although he assumed that this movement upshore with the incoming tide was restricted.

To what extent does traditional fish classification (based only on the low-tide period) make any sense for at least some of the species? The zonation patterns have been determined mostly from the study of sessile organisms, which after the larval stage present no mobility. Fish zonation may be governed by different factors, since they are mobile and may be able to actively select their habitat (Gibson 1967b). The tidal influence is most likely felt well below the intertidal limit, since the effect of turbulence extends down for several metres beneath the water surface. A possible example of this influence concerns Parablennius pilicornis; this species shows an increment of activity during high tide, although almost all individuals remain in the subtidal. This finding may be easily explained if we assume that this fish tends to avoid swimming in turbu- 
lent waters. Indeed, as the tide rises the waves break higher on shore and the effects of wave-induced turbulence will be less intense in the subtidal. Preliminary observations on other rocky shores suggest that the upper limit of distribution of $P$. pilicornis is determined by water turbulence, so that in sheltered shores they occur much closer to the intertidal limit than at exposed sites (V. C. Almada pers. obs.).

In addition to the zonation patterns found, the different species also presented some variance in their substratum preferences (e.g. rock, boulders, sand). These substratum preferences are similar to those described for low tide (e.g. Macpherson 1994, Faria et al. 1998, Mesa \& Vacchi 2005), with the important difference that, when the tide is high, large Gobius cobitis are found on exposed rocky substratum. This conclusion must, however, be viewed as preliminary, because not all types of substrata were represented at all depth levels.

Taken together, our findings indicate that, while the low-tide studies centred on pools give an idea of the fish assemblage when it is less active and packed in restricted shelters, the observations in other tidal phases are likely to provide new insights on the niches of each individual species when it is most active and on a number of interspecific differences in ecology that would hardly be captured at low tide.

During high tide, the patterns of space utilisation of the more common intertidal fish species of the studied area, Coryphoblennius galerita, Gobius cobitis and Lipophrys pholis, differed among species. C. galerita, the smallest species, seems to keep an approximately constant position at a given level of the shore, probably limiting its movements to short excursions in the vicinity of the shelters they use during low tide. The largest species, G. cobitis and L. pholis, especially the larger individuals of the latter species, seem to move up and down with the tide, probably maximising submersion time and feeding opportunities. Thus, the available evidence indicates that the 2 hypotheses formulated in the 'Introduction' section are both valid, depending on species and life stage. One possible explanation for this is the fact that, whereas C. galerita remains in the tidal pools as juveniles and adults-except during breeding, when males leave the pools to nest in small shelters returning after the end of the breeding period (e.g. Faria et al. 1998, Faria \& Almada 2001)-G. cobitis and L. pholis use the tidal pools as juveniles and move to large crevices or channels as adults (Faria \& Almada 2001). Other studies (e.g. Gibson 1967b, Milton 1983) have also referred to the possibility of downshore migrations of larger fish seeking adequate shelters, which are more frequently available down the shore.

These different patterns of utilisation of the intertidal zone during low tide by these species imply that, whereas Coryphoblennius galerita is already in the main intertidal area when the tide rises, the larger individuals of Lipophrys pholis and probably Gobius cobitis must move up into the intertidal, taking advantage of the incoming water and must move down with the ebbing tide to reach their low-tide refuges.

These movements are probably related to feeding activities. Indeed, a relatively large number of feedingrelated activities was observed during the rising and high-tide period. The food items of these species are well known (see Qasim 1957, Gibson 1970, Milton 1983, Monteiro et al. 2005). In the case of Lipophrys pholis, feeding is mainly based on gastropods, barnacles and algae, with a minor proportion of mobile organisms like amphipods, copepods and isopods. All these types of prey are especially abundant on intertidal rocky platforms (Milton 1983). In the case of Gobius cobitis the situation is less clear. Although described as a herbivore in some studies (e.g. Wheeler 1969), during the present study it was never seen grazing food from rock surfaces and was typically found quietly waiting on rocks as an ambush predator. On several occasions, this species was observed attacking and eating small fish (a fact already noted by Gibson 1970), including L. pholis. It is more likely piscivorous, taking advantage of movements of other intertidal fishes.

Burrows et al. (1999), videotaping the movements of Lipophrys pholis over almost an entire tidal cycle, showed that it was more active during the daytime and that there were more fish active in the morning and during the rising tide or in the high-tide period than during the ebbing tide, presenting more convoluted paths during the rising tide. These authors suggested that the differences noted may be related to foraging behaviour. On the flood tide, at the beginning of the day and after the low-tide period, the fish should be hungrier and thus stimulated to feed. Ralston \& Horn (1986), using ultrasonic telemetry, also obtained a similar result for Cebidichthys violaceus (Girard, 1854). Gibson (1982) pointed out that in those rocky shore fishes that show periodicity in the laboratory, the activity peaks are usually centred on the predicted time of high tide. However, as Ralston \& Horn (1986) have pointed out, it seems that the early advance of the tide apparently contains important cues for these fishes to begin activity. This seems to be an area that deserves more attention in the future.

Acknowledgements. Part of this study was supported by Fundação para a Ciência e Tecnologia (FCT) within the Plurianual Program (UI\&D 331/94) and by FCT and FEDER within the Project POCTI/BSE/46825/2002. C.F. was also supported by a grant from FCT (SFRH/BPD/14478/2003). We thank C. Luís, C. Silva and S. Francisco, who helped with the field work, and C. Amorim, who revised the English. 


\section{LITERATURE CITED}

Almada VC, Gonçalves EJ, Oliveira RF, Barata EN (1992) Some features of the territories in the breeding males of the intertidal blenny Lipophrys pholis (Pisces: Blenniidae). J Mar Biol Assoc UK 72:187-197

Antunes MM, Cunha PL, Duarte AP, Mendonça EP (1988) Ria de Alvor as a spawning place and nursery ground. J Fish Biol 33(Suppl A):185-190

Beja PR (1995) Structure and seasonal fluctuations of rocky shore littoral fish assemblages in south-western Portugal: implications for otter prey availability. J Mar Biol Assoc UK 75:833-847

Black R, Miller RJ (1991) Use of the intertidal zone by fish in Nova Scotia. Environ Biol Fish 31:109-121

Burrows MT, Gibson RN, Robb L, Comely C (1994) Temporal patterns of movement in juvenile flatfishes and their predators: underwater television observations. J Exp Mar Biol Ecol 177:251-268

Burrows MT, Kawai K, Hughes RN (1999) Foraging by mobile predators on a rocky shore: underwater TV observations of movements of blennies Lipophrys pholis and crabs Carcinus maenas. Mar Ecol Prog Ser 187:237-250

Carlisle DB (1961) Intertidal territory in fish. Anim Behav 9: 106-107

Corbera J, Sabatés A, Garcia-Rubies A (1996) Peces de mar de la Península Ibérica. Editorial Planeta, Córcega

Darwall WRT, Costello MJ, Donnelly R, Lysaght S (1993) Implications of life history strategies for a new wrasse fishery. J Fish Biol 41B:111-123

Estabrook CB, Estabrook GF (1989) ACTUS: a solution to the problem of small samples in the analysis of two-way contingency tables. Historical Methods 22:5-8

Faria C, Almada V (1999) Variation and resilience of rocky intertidal fish in western Portugal. Mar Ecol Prog Ser 184:197-203

Faria C, Almada V (2001) Microhabitat segregation in three rocky intertidal fish species in Portugal: Does it reflect interspecific competition? J Fish Biol 58:145-159

Faria C, Almada V, Nunes MC (1998) Patterns of agonistic behaviour, shelter occupation and habitat preference in juvenile Lipophrys pholis, Coryphoblennius galerita and Gobius cobitis. J Fish Biol 53:1263-1273

Gibson RN (1967a) Experiments on the tidal rhythm of Blennius pholis. J Mar Biol Assoc UK 47:97-111

Gibson RN (1967b) Studies on the movements of littoral fish. J Anim Ecol 36:215-234

Gibson RN (1970) Observations on the biology of the giant Gobius cobitis Pallas. J Fish Biol 2:281-288

Gibson RN (1971) Factors affecting the rhythmic activity of Blennius pholis L. (Teleostei). Anim Behav 19:336-343

Gibson RN (1972) The vertical distribution and feeding relationships of intertidal fish on the Atlantic coast of France. J Anim Ecol 41(1):189-207

Gibson RN (1982) Recent studies on the biology of intertidal fishes. Oceanogr Mar Biol Annu Rev 20:363-414

Gibson RN (1986) Intertidal teleosts: life in a fluctuating environment. In: Pitcher TJ (ed) The behaviour of teleost fishes. Croom Helm, London, p 388-408

Gibson RN (1999) Movement and homing in intertidal fishes. In: Horn MH, Martin KLM, Chotkowski MA (eds) Intertidal fishes. Life in two worlds. Academic Press, San Diego, CA, p 97-125

Gibson RN, Yoshiyama RM (1999) Intertidal fish communities. In: Horn MH, Martin KLM, Chotkowski MA (eds) Intertidal fishes. Life in two worlds. Academic Press, San Diego, CA, p 264-296

Green JM (1971) High tide movements and homing behaviour of the tidepool sculpin Oligocottus maculosus. J Fish Res Board Can 28:383-389
Henriques M, Almada VC (1998) Juveniles of non-resident fish found in sheltered rocky subtidal areas. J Fish Biol 52: 1301-1304

Horn MH, Martin KLM, Chotkowski MA (1999) Intertidal fishes. Life in two worlds. Academic Press, London

Laegdsgaard P, Johnson CR (1995) Mangrove habitats as nurseries: unique assemblages of juvenile fish in subtropical mangroves in eastern Australia. Mar Ecol Prog Ser 126:67-81

Layman CA (2000) Fish assemblage structure of the shallow ocean surge-zone on the eastern shore of Virginia Barrier Islands. Estuar Coast Shelf Sci 51:201-213

Lenanton RCJ, Potter IC (1987) Contribution of estuaries to commercial fisheries in temperate western Australia and the concept of estuarine dependence. Estuaries 10:28-35

Macpherson E (1994) Substrate utilization in a Mediterranean littoral fish community. Mar Ecol Prog Ser 114:211-218

Macpherson E (1998) Ontogenetic shifts in habitat use and aggregation in juvenile sparid fishes. J Exp Mar Biol Ecol 220(1):127-150

Macpherson E, Raventos N (2005) Settlement patterns and post-settlement survival in two Mediterranean littoral fishes: influences of early-life traits and environmental variables. Mar Biol 148(1):167-177

Martin P, Bateson P (1993) Measuring behaviour, 2nd edn. Cambridge University Press, Cambridge

Mesa GL, Vacchi M (2005) Analysis of the blennioid assemblages associated with different rocky shore habitats in the Ligurian Sea. J Fish Biol 66:1300-1327

Milton P (1983) Biology of littoral blenniid fishes on the coast of south-west England. J Mar Biol Assoc UK 51:247-265

Monteiro NM, Quinteira SM, Silva K, Vieira MN, Almada VC (2005) Diet preference reflects the ontogenetic shift in microhabitat use in Lipophrys pholis. J Fish Biol 67(1): $102-113$

Nash RDM, Santos RS, Hawkins SJ (1994) Diel fluctuations of a sandy beach fish assemblage at Porto Pim, Faial Island, Azores. Arquipélago-Life and Marine Sciences 12A: 75-86

Potts GW (1985) The nest structure of the corkwing wrasse, Crenilabrus melops (Labridae: Teleostei). J Mar Biol Assoc UK 65:531-546

Qasim SZ (1957) The biology of Blennius pholis L. (Teleostei). Proc Zool Soc Lond 128:161-208

Ralston SL, Horn MH (1986) High tide movements of the temperate-zone herbivorous fish Cebidichthys violaceus (Girard) as determined by ultrasonic telemetry. J Exp Mar Biol Ecol 98:35-50

Rangeley RW, Kramer DL (1995) Use of rocky intertidal habitats by juvenile pollock Pollachius virens. Mar Ecol Prog Ser 126:9-17

Sayer MD, Cameron KS, Wilkinson G (1994) Fish species found in the rocky sublittoral during winter months as revealed by the underwater application of the anaesthetic quinaldine. J Fish Biol 44:351-353

Taborsky M, Limberger D (1980) The activity rhythm of Blennius sanguinolentus Pallas, an adaptation to its food source. PSZN I: Mar Ecol 1:143-153

Wheeler A (1969) The fishes of the British Isles and north west Europe. Macmillan, London

Whitehead PJP, Beauchot ML, Hureau JC, Nielsen, J, Tortonese E (1986) Fishes of the north-eastern Atlantic and the Mediterranean. UNESCO, Bungay

Williams GC (1957) Homing behaviour of California rocky shore fishes. Univ Calif Publ Zool 59:249-284

Yoshiyama RM, Sassaman C, Lea RN (1986) Rocky intertidal fish communities of California: temporal and spatial variation. Environ Biol Fish 17(1):23-40

Zander CD (1972) Beiträge zur Ökologie und Biologie von Blenniidae (Pisces) des Mittelmeeres. Helgol Wiss Meeresunters 23:193-231 